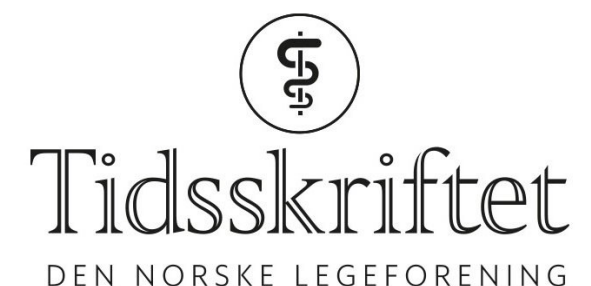

\title{
Den gode død
}

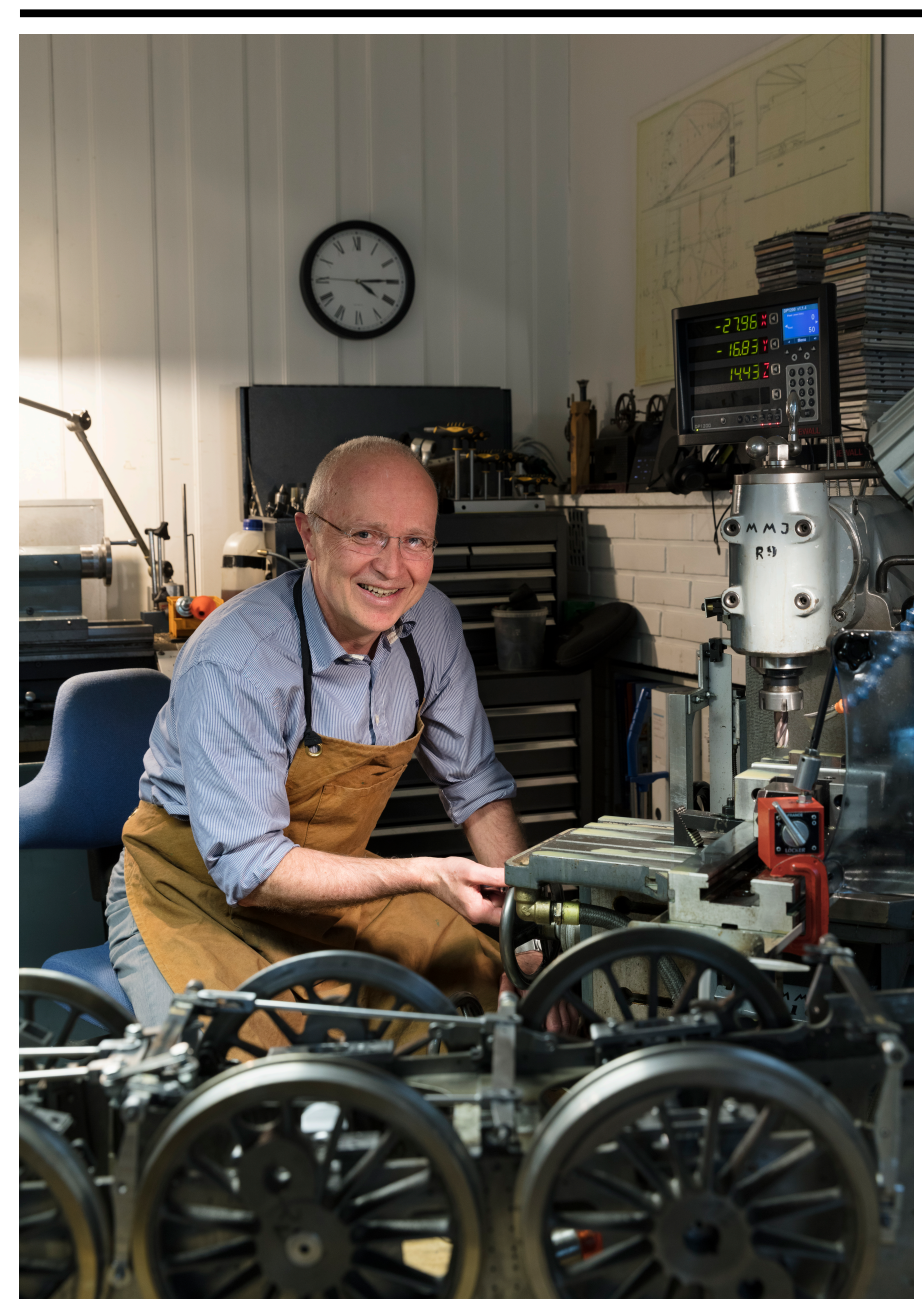

INTERVJU

\section{JANNIKE REYMERT}

E-post: jannike.reymert@gmail.com

Stephan Ore brenner for gode sykehjem der beboerne får fullverdig omsorg i livets siste fase. Selv drømmer han om en avansert, intelligent og kompetent pleierobot som yter hjelp og service akkurat når og på den måten han vil ha det.

Stephan Ore inviterer meg hjem for å samtale om jobben på Oppsal sykehjem. Litt hemmelighetsfull forteller han at en av familiens to stuer er innredet som verksted.

- Ja, du kan få se det etterpå hvis du vil, sier han og trekker paralleller mellom 
utviklingsarbeidet han driver ved sykehjemmet og det å bruke hendene til fritidssysler.

- Jeg blir glad av å få til noe praktisk. Du kan godt kalle meg verktøynarkoman. Jeg er ingen teoretiker eller klassisk akademiker, og det tror jeg er en styrke i jobben min som sykehjemslege. Der må vi hele tiden improvisere. Jeg bruker fiksementaliteten min hver eneste dag på jobben.

\section{Forbedringsarbeid}

De siste åtte årene har Stephan Ore jobbet i full stilling som sykehjemslege. Han kan ikke få fullrost sin arbeidsgiver Norlandia, hotellkjeden som de siste årene blant annet har drevet en del norske sykehjem.

- Etter å ha opplevd offentlig helseledelse på sitt verste, valgte jeg å slutte som fastlege og sykehjemslege. Arbeidsgiveren jeg har nå, har en "bottom-up"-filosofi i sin ledelseskultur. De spør meg: "Hva trenger du for å gjøre en god jobb?” Kvalitet er viktigere enn kvantitet. Jeg får lov til å bruke en dag i uken til utviklingsarbeid mot å være mer tilgjengelig på telefon fra sykehjemmet resten av uken. Den måten de behandler meg på, har fyrt meg opp jeg brenner for jobben.

- Dette stemmer lite med det vi leser i avisene, der de private sykehjemsaktørene ofte får kritikk for å drive institusjonene med profittjag som hovedmotivasjon.

- Ja, det er en del kritikk av private omsorgsinstitusjoner. Min erfaring er at når det gjelder ledelse, har min arbeidsgiver en oppdatert holdning, mens det offentlige har stagnert i en amerikanskinspirert industriledelseskultur fra 1950-årene med silotenking og ovenfra-ognedad-strukturer.

\section{Eldremedisin}

Ore har benyttet årene som tilsynslege til å involvere seg i Referansegruppen for sykehjemsmedisin, en forløper for Norsk forening for alders- og sykehjemsmedisin. Der var han leder fra 2010 til 2015. 


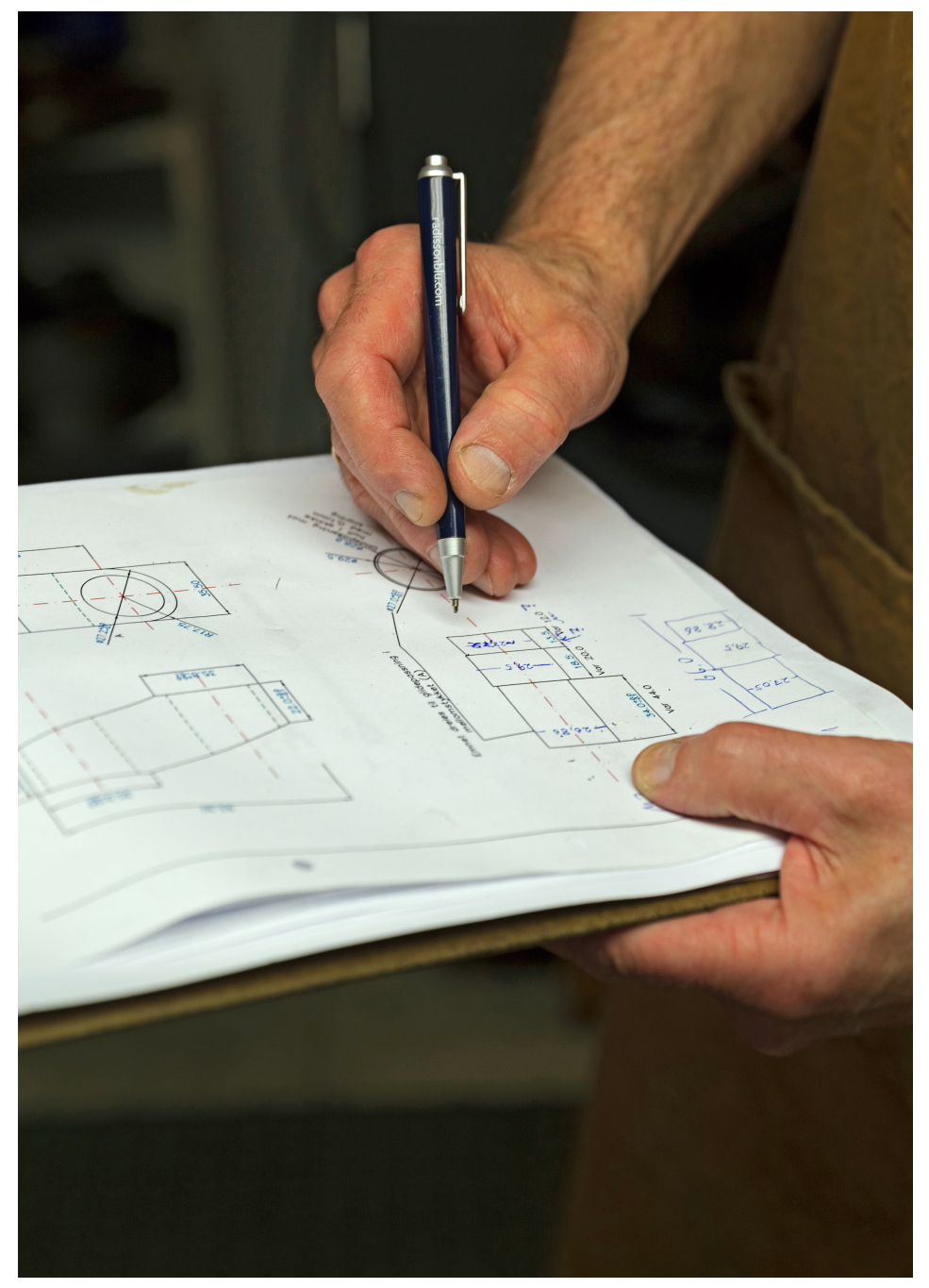

- Du har sikkert gjort deg noen tanker om at sykehjemsmedisin ikke er en egen spesialitet?

- Etter mitt syn er det hevet over tvil at vi må få en egen spesialitet. Såpass respekt må man ha for et så krevende fagfelt. Spesialiteten bør hete eldremedisin, for å skille den fra geriatrien. I Norge har vi i dag 450 årsverk i sykehjem - det er jo et stort fagfelt både i kjøttvekt og i faglig tyngde. Slik situasjonen er nå, får vi ikke tak i de unge, dyktige legene. Vi mister dem i løpet av få år fordi de ikke finner en god karrierevei. De blir tvunget inn i et spesialiseringsløp i allmennmedisin. Det er umulig å holde på spesialiteten i allmennmedisin og samtidig være en dedikert sykehjemslege.

- Det du nå fremsnakker, kan passe godt inn i de store byene. Mange mindre kommuner har ikke plass for heltidsansatte sykehjemsleger.

- Jeg ser for meg to typer sykehjemsleger. I de store byene og i store kommuner vil de ha sitt virke bare på sykehjem, mens allmennlegene i de små kommunene kan få en videreutdanning innen eldremedisin slik at deres kompetanse heves tilstrekkelig til at de kan kalle seg eldreleger. 


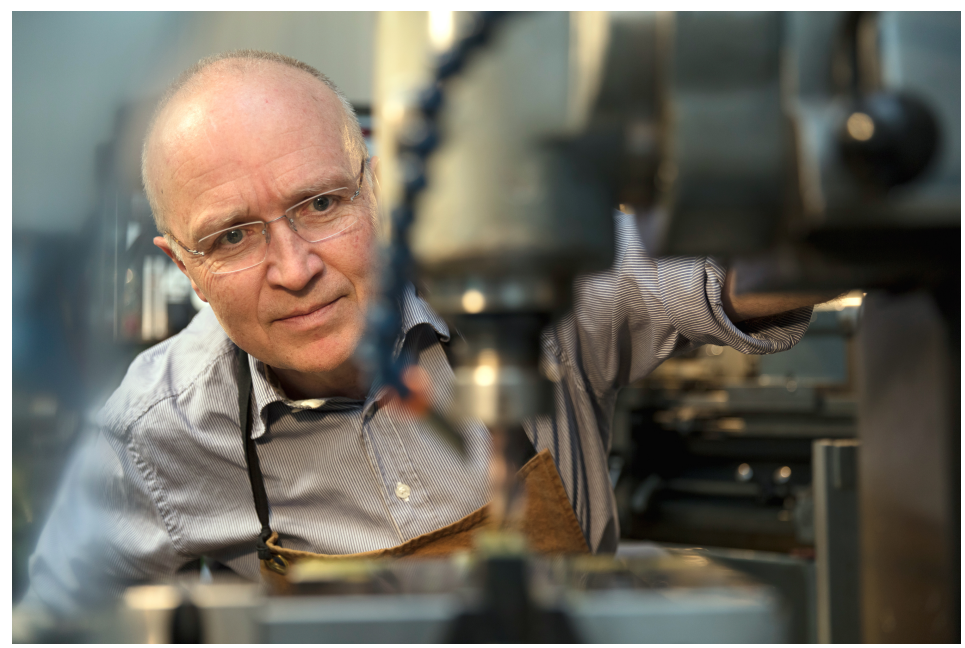

\section{Livets siste fase}

- Hva var det som gjorde at du tente på sykehjemsmedisinen?

- Det kan kanskje høres rart ut, men helt fra studietiden har jeg vært interessert i livets siste fase. Det handler om livslinjer som ender i et punkt der det er slutt. For meg er det en god følelse av ærlighet og oppriktighet at vi stopper opp og tar innover oss at det en gang er slutt. Andre kan bruke livet på å løpe rundt og styre med det som er viktig for dem der og da, men for meg gir det liten dybdeforståelse av livet. Den gode død er en del av det gode liv. Livet blir mer fargerikt når det speiler seg mot den intetheten som døden representerer. Den viktigste boken jeg har lest de siste årene, Å vare dødelig av Atul Gawande, handler blant annet om dette. Den anbefales hermed på det varmeste!

Arbeidet som sykehjemslege nå som karrieren er på hell har ikke dempet Stephan Ores faglige kreativitet Han har nylig fullført Norges høyeste utdanning i kvalitetsarbeid for leger, "forbedringsutdanning for leger". I etterkant har hans arbeidsgiver gitt ham tillit og armslag til å ta i bruk mye av det han lærte.

Han har gjennomført mange endringer på Oppsalhjemmet for å bedre hverdagen til brukerne, de ansatte og de pårørende. Her kan nevnes at de spør alle nye beboere: "Hva er viktig for deg?" De blir også spurt om hvilket navn de foretrekker at de ansatte bruker, og alle pasientene blir fotografert. Bildet henges opp på en stor risikotavle på vaktrommet sammen med annen kritisk informasjon om hver enkelt. På den måten kan de ansatte ha størst mulig vekt på at beboeren er en person som har hjemmet sitt på sykehjemmet.

- Jeg opplever at jeg har to jobber. Den ene handler om å utføre legegjerningen best mulig, den andre om å gjøre jobben bedre. Målet mitt er å bli best i å bli bedre.

Stephan Ore mener det er et problem at vi har for lite forbedringskunnskap. Fra en medisinsk nyvinning er tilgjengelig til den er implementert $\mathrm{i}$ helsevesenet tar det $\mathrm{i}$ gjennomsnitt 17 år.

- Vi trenger ikke alltid mer forskning, vi trenger mer kunnskap om hvordan vi skal endre våre rutiner til det bedre. Grunnen til at jeg liker dette arbeidsfeltet så godt, er at jeg liker å se ting skje. Jeg har ikke tålmodighet til forskning. Forskerne og de som implementerer ny kunnskap i det praktiske liv, er avhengige av hverandre. Vi som jobber med forbedringskunnskap, fyller ut hullene mellom det forskerne viser. Kunnskapsbasert medisin kan ikke alene gi oss det vi trenger for å forbedre hverdagen for våre pasienter. Vi praktikere skaper et rom for hypoteser når vi prøver ut den kunnskapen forskerne bringer til oss. Jeg liker å være nær pasientene og fikse konkrete problemer.

Nå er Ore selvgående i praten, mine forberedte spørsmål blir liggende på blokken.

- Nå er for eksempel legemiddelgjennomgang i søkelyset. Jeg tror vi leger er altfor opptatt av å følge retningslinjer. De sier mye om når du skal begynne med ulike tiltak, men nesten 
ingenting om når du skal slutte, noe vi som jobber på sykehjem bør vektlegge. Min erfaring er at vi ikke stopper tidsnok med alle medisinene pasienten er blitt satt på opp gjennom livet. Medisinering i sykehjem er i prinsippet eksperimentell medisin, siden ingen retningslinjer har inkludert denne pasientgruppen i sine bakgrunnsdata. Det er tall som tyder på at 1 200-1 500 mennesker dør årlig som direkte følge av medisinbivirkninger. Tenk da på alle den lidelsen vi i tillegg påfører mange pasienter selv om de ikke dør av vår medisineringsiver. Det er ikke nødvendigvis polyfarmasien vi vil til livs, men dysfarmasien, noe Steinar Madsen, medisinsk fagdirektør ved Statens legemiddelverk, så presist uttalte nylig.

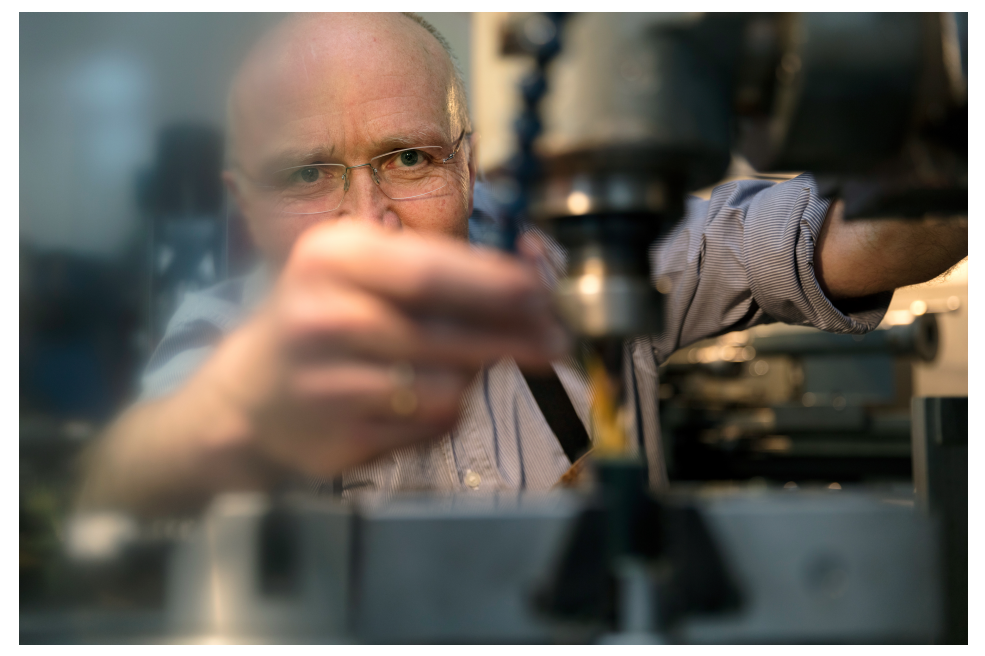

\section{Fem valg for verdighet}

Stephan Ore har utviklet et dokument som beboerne på Oppsalhjemmet er med på å fylle ut ved ankomst. Det handler om å avklare ønsker de har for hvordan de vil bli behandlet når livet går mot slutten - et livstestament.

- Hvordan tar beboerne på sykehjemmet det at du går rett på sak om det de kanskje aldri har satt ord på før?

- Våre nye beboere ønsker som oftest en åpen og ærlig tone fra oss, selv i den første samtalen vi har. Forskning fra utlandet viser at en tidlig samtale mellom lege og pasient om livskritiske spørsmål og behandlingsavklaring er uproblematisk og oppklarende. Det har vært flere som har takket meg i etterkant. De fleste eldre har allerede tumlet med disse spørsmålene, men har ikke hatt så mange de har tort å snakke med det om. Noen ganger velger vi å utsette de vanskeligste spørsmålene, men erfaringen viser at hvis vi skal vente til "det riktige tidspunktet", vil vi neppe finne det før det er for sent. Ofte handler dette mer om legens enn om pasientens frykt for de vanskelig spørsmålene. Jeg må legge til at livstestamentet også åpner for at beboeren ikke tar stilling til spørsmålene dersom det er det som føles best for dem.

I disse dager er Ore i gang med å revidere dokumentet og å utvikle et multikulturelt dialogverktøy for beslutninger i livets sluttfase.

- Vår individorienterte kultur er på kollisjonskurs med mange innvandrergrupper som har en kollektivistisk tilnærming til hvordan de vil behandle sine gamle. I norsk kultur holdes familien litt på sidelinjen i eldreomsorgen, mens mange innvandrerfamilier lever veldig tett på sine eldre, syke familiemedlemmer, også når de har fått plass på et sykehjem, sier han.

- Jeg husker godt den døende, demente asiatiske mannen jeg hadde ansvar for. Da det gikk mot slutten, var det ikke mindre enn 18 familiemedlemmer inne på rommet. Den utpekte pårørende "forhandlet" med meg og satte mine etiske prinsipper på strekk, siden de fant det uhørt ikke å gi antibiotika da den døende mannen fikk feber. Senere har jeg forstått at 
det handlet om ivaretakelse av den pårørendes ære overfor storfamilien. Dette må vi lære mer om - ikke det å gi etter for urimelige krav, men å forstå og takle den pårørendes situasjon bedre. Vi har nå fått med oss tungvektere i det palliative miljøet til å jobbe sammen om dette prosjektet, forteller han og fortsetter:

- Jeg tror det er viktig med et godt nettverk i arbeidet med mennesker i livets sluttfase. Derfor er jeg med på å dra i gang et internasjonalt kommunikasjonsnettverk rundt hvordan vi i helsevesenet skal legge til rette for pasienter og pårørende i livets siste fase. Å ha de pårørende med på laget skal være mer enn en festtale, det er helt nødvendig - selv om det av og til byr på store utfordringer. Jeg opplever stadig oftere at de kommer med noe som ligner på shoppinglister over hva de forventer at vi skal stille opp med for deres døende eldre. Urealistiske krav, som innebærer at andre med mindre krevende pårørende får mindre, er vanskelig å håndtere. Her tror jeg det ofte er skyldfølelse og ubearbeidet sorg som driver dem, sier han.

- Min jobb blir da å bygge tillit samtidig som jeg realitetsorienterer dem om hva vi kan få til og - ikke minst - hva de eldre har godt av. Yngre mennesker har ofte overdreven tro på at trening og aktivisering er bra for deres gamle, mens vi ser at de ofte har så lite krefter at det å gjennomføre daglig stell og dagens måltider tar det de har av kapasitet og gjør at de trenger hvile resten av dagen.

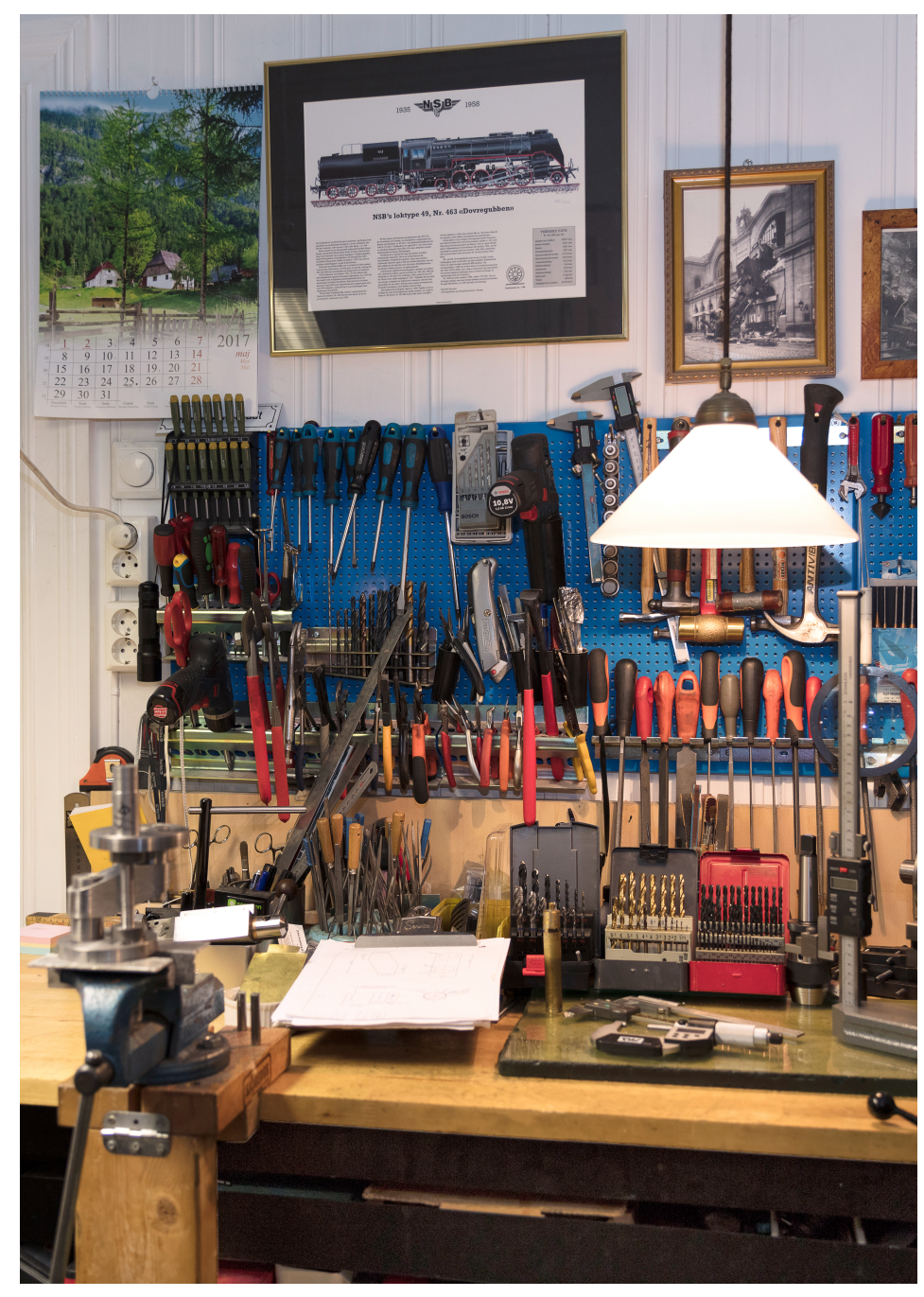

\section{Orlando}

Høsten 2016 satt Stephan seg på flyet til USA for å delta på verdens største

kvalitetskonferanse i Orlando for tredje gang. Denne gangen hadde han med seg litt ekstra i kofferten, et godt forberedt innlegg om kvalitetsarbeidet han driver på Oppsalhjemmet. Han fikk holde innlegget under hovedkonferansen. 
- Jeg tør påstå at man tidligere på denne konferansen ikke har sett maken fra et sykehjem der personliggjøring av pasienten står i sentrum. I sykehjem er det mye sykehustenkning, men det har vi ikke behov for i en langtidsavdeling. Forholdene der skal ligne på et hjem, ikke en steril sykehusavdeling. Vi ser nå et paradigmeskifte fordi denne tenkningen åpner øynene våre for hva et sykehjem faktisk kan utvikles til.

- Har du gjort deg noen tanker om hva slags behandling du ønsker for deg selv hvis du en gang blir sykehjemspasient?

- Jeg drømmer om en avansert, intelligent og kompetent pleierobot som yter meg hjelp og service akkurat når jeg ønsker det og på den måten jeg foretrekker. Du blir sikkert overrasket over svaret, men dette har med autonomi å gjøre. Det å tenke seg at andre mennesker skal pleie meg føles vanskelig, jeg vil helst slippe den kroppslige nærheten med mer eller mindre fremmede det innebærer. Jeg vil heller ha nærkontakt med andre på de arenaene jeg trives på. Videre ser jeg for meg en tilværelse der jeg rekker å se de tusen gode filmene jeg ikke har rukket å se i yngre alder. Hvis jeg svikter kognitivt, tror jeg god musikk vil gjøre samme nytten.

\section{Verkstedet}

Samtalen vår har vært intens og innholdsrik. I min iver etter å få med meg alt har jeg glemt at han ville vise meg familiens to stuer. Den første byr ikke på store overraskelser, den andre overgår til gjengjeld alt jeg noensinne har sett gå inn under begrepet "stue". Hele rommet er møblert som et mekanisk verksted der intet verktøy synes å mangle. Midt i rommet troner en gedigen dreiebenk der et halvferdig to meter langt damplokomotiv troner i all sin prakt. Rundt i rommet ligger halvferdige hjul, akslinger og annet materiale i stål. På veggen henger en arbeidstegning av Dovregubben, Norges største damplokomotiv noensinne.

Sammen med en kamerat har Stephan Ore siden 2009 bygd en 1: 8-modell av Dovregubben. Med få unntak lager de alle deler for hånd. Arbeidet er ikke ferdig før lokomotivet kan brukes i det praktiske liv. Da snakker vi om at de lar inntil ti barn få en kullfyrt kjøretur på Teknisk museum på søndager.

- Dette må kreve tålmodighet. Hvordan stemmer det med din tidligere bekrivelse av deg selv som en som liker å få ting til å skje fort?

- Tja, jeg er kanskje litt mer petimeter enn jeg ga uttrykk for. Men også her er målet å få et produkt som fungerer. Mer presisjon krever jeg ikke, sier han og klapper kjærlig på et produkt som etter min ringe vurderingsevne er en bortimot perfekt kopi av en svært komplisert maskin.

Selv om han åpenbart har brukt utallige timer på denne hobbyen, presiserer han at hans altoppslukende interesse er arbeidet som sykehjemslege. Med et lite sukk konstaterer han at han er en heldig mann som i tillegg til å stortrives på jobb kan glede seg til å komme hjem og bygge videre på sitt praktfulle damplokomotiv. Hvis han en gang skal flytte på sykehjem, har nok utviklingen kommet så langt at de finner plass til både ham og hans damplokomotiver. Da er det seg selv han kan takke for at man ved norske sykehjem har tatt mål av seg å være et hjem for beboerne og ikke en steril institusjon uten rom for pasientenes personlige preferanser.

\section{Stephan Ore}

Født 19. juli 1954

- Cand.med. Universitetet i Oslo 1981

- Allmennlege i Innbygda, Trysil 1984

- Barneavdelingen Ullevål sykehus 1985 
- Ring Medisinske Senter, senere Volvat Medisinske Senter, allmennseksjonen 1985-94

- Eiksmarka legekontor 1994-2013 som fastlege pluss deltid ved Østerås sykehjem

- Sykehjemslege ved Oppsalhjemmet Norlandia Oslo fra 2009

- Leder av referansegruppen for sykehjemsmedisin i flere år

- Leder av sakkyndigkomiteen for kompetanseområdet alders- og sykehjemsmedisin og første leder i spesialforeningen Norsk forening for alders- og sykehjemsmedisin

Publisert: 26. juni 2017. Tidsskr Nor Legeforen. DOI: 10.4045/tidsskr.17.0262

(C) Tidsskrift for Den norske legeforening 2020. Lastet ned fra tidsskriftet.no 